\title{
Respecting Life: A Human Obligation
}

\author{
A New Environmental Ethics: The \\ Next Millennium for Life on Earth. \\ Holmes Rolston III. Taylor and Francis \\ (Routledge), 2012. 246 pp., illus. \$31.95 \\ (ISBN 9780415884846 paper).
}

$\mathbf{T}$ he richness of the field of environmental ethics is, for the most part, fully showcased in Holmes Rolston III's new book, A New Environmental Ethics: The Next Millennium for Life on Earth. The book should be a landmark publication for the discipline, from one of its greatest founders and practitioners, but it falls short. Many chapters are inspiring, however, especially those in which his deep knowledge of science is coupled with his outright religious appreciation of all of Earth's life and history.

A New Environmental Ethics returns to the major topics that Rolston, as a college professor and true teacher, has discussed through the years. The tone of the whole book is that of an extended lecture. Each chapter reveals his unusually poetic prose and his wide-ranging knowledge of most of the developments in the field of environmental ethics, a discipline in which he first taught in 1973 and one that has blossomed ever since. Rolston mentions many of the books, collections, and anthologies but misses one of the best- the late Louis P. Pojman's anthology (Pojman and Pojman 2012), which allowed philosophers to speak in their own voice, rather than offering canned versions of their thoughts.

Among the strengths of the book is Rolston's outstanding, in-depth treatment of organisms, species, natural systems, wilderness, and nature's intrinsic value. Equally outstanding is his encyclopedic (although, at times, selective) knowledge of the field of environmental ethics as he tackles broader and more far-reaching issues.

The problematic aspects of his work become apparent in his discussion of environmental justice-an expanding area of environmental thought that is worthy of greater coverage. His approach is visibly limited when he states that "the record of globalization for bettering the poor is impressive" (p. 203) or when he says that international global markets, together with religion, are evidence that "it looks as though humans do learn a sense of global concern and fairness" (p. 203) or when he approvingly cites Nobel Prize-winning economist Amartya Sen, saying that "development... increases freedom" (p. 205), all of which indicates a somewhat superficial knowledge of the issues involved. Despite paying lip service to the concept of leaving an ecological footprint and acknowledging that "the poorer nations are likely to suffer the most" (p. 212) when referring to the effects of climate change, Rolston sees United States-style, corporatedominated capitalism as the only game in town rather than noting the abundant literature that criticizes the status quo, both within the United States (Miller 1987) and across the globe (Mattei and Nader 2008).

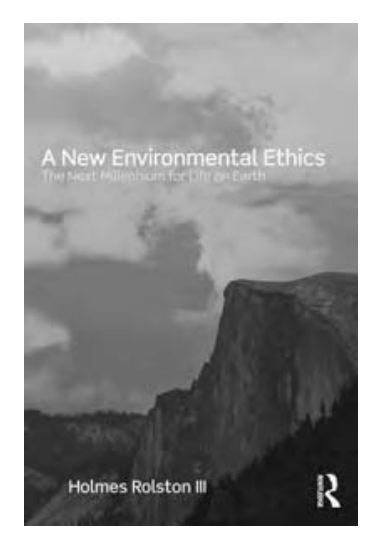

It may be wrong to seek insight within the themes that are peripheral to Rolston's real strength, which is the unique way he approaches both the various aspects of the wild and the various positions that environmental ethicists have held on theoretical issues. A key issue of Rolston's is that of intrinsic value, a topic that has engaged environmental philosophers for decades. He comments that "we will be arguing that wilderness is set aside both for people and on account of intrinsic values there and that the two are complementary" (p. 50). This is where Rolston excels. In chapter 4, "Organisms: Respect for life," he takes on other philosophers in defense of intrinsic value: "An organism is thus a spontaneous cybernetic system, selfmaintaining, sustaining, and reproducing itself on the basis of information about how to make a way in the world" (p. 116). He concludes that the "ongoing planetary natural history" demonstrates a certain creativity emanating from the "achievements of natural history" (p. 122). It is his basic reason for respecting such life and for this respect to be a human obligation. A similar argument in chapter 5, "Species and biodiversity: Lifelines in jeopardy," supports the importance and value of species and biodiversity: "In threatening Earth's biodiversity, the wrong that humans are doing is stopping the historical vitality of life" (p. 154).

Chapter 6, "Ecosystems: The land ethic," starts with the famous passage by Aldo Leopold: "A thing is right when it tends to preserve the integrity, stability, and beauty of the biotic community. It is wrong when it tends [to do] otherwise" (p. 158). Without entering into the scientific arguments for and against the laws of ecology, or on the meaning of community, or other related debates, we can say with Rolston that "ecosystems seem to function well [and to be] more or less stable or flourishing and to have their integrity" (p. 165). To explain the term integrity, Rolston

doi:10.1525/bio.2013.63.1.11 
cites Karr and Dudley (1981), but there have been copious amounts of literature on the subject since then (Karr and Chu 1999, Karr 2000), culminating with a multiauthored definition of ecological integrity in Pimentel and colleagues (2000). Related work continues today after 20 years of collaboration by the 250-plus members of the Global Ecological Integrity Group (GEIG), although during the last decade, much emphasis has been on the legal dimensions of the concept. (The phrase biological integrity first appeared in 1972 in both the Clean Water Act [33 U.S.C. $\$ 1251$ et seq. 1972] and in the Great Lakes Water Quality Agreement [ $w w w$. epa.gov/glnpo/glwqa/1978].)

The reasons for our obligation to respect ecological integrity are similar to those that Rolston advocates in support of organisms and, ultimately, all life on Earth: "Viewed in depth, these ecosystems remain today the source and support of individuals and species alike" (p. 167). Therefore, the defense of the biological integrity of ecosystems represents the true meaning of sustainability (Bosselmann 2008). There is also a growing number of articles and books and even a new journal linking human rights to ecology in law (Taylor 1998, Westra 2006) - many works originating from the meetings of the GEIG.

Ignoring the importance of ecological integrity in the development of environmental thought in his book has led Rolston to bypass an extremely important international document: the Earth Charter, which he helped to draft with Steven Rockefeller, among others. The document (considered "soft law" at this time) cites ecological integrity as one of its most important principles.

In the final pages of A New Environmental Ethics, in chapter 7, "Earth: Ethics on the home planet," Rolston does return to the topic of integrity: "We are Earthlings. Our integrity is inseparable from Earth['s] integrity" (p. 220). I am convinced that most environmentalists, including each and every member of the GEIG, would gladly join with me in saying amen to that.

\section{References cited}

Bosselmann K. 2008. The Principle of Sustainability: Transforming Law and Governance. Ashgate.

Karr JR. 2000. Health, integrity, and biological assessment: The importance of measuring whole things. Pages 209-226 in Pimentel D, Westra L, Noss RF, eds. Ecological Integrity: Integrating Environment, Conservation, and Health. Island Press.

Karr JR, Chu EW. 1999. Restoring Life in Running Waters: Better Biological Monitoring. Island Press.

Karr JR, Dudley DR. 1981. Ecological perspective on water quality goals. Environmental Management 5: 55-68.

Mattei U, Nader L. 2008. Plunder: When the Rule of Law Is Illegal. Wiley-Blackwell.

Miller AS. 1987. Corporations and our two constitutions. Pages 241-262 in Samuels WJ, Miller AS, eds. Corporations and Society: Power and Responsibility. Greenwood Press.

Pimentel D, Westra L, Noss RF, eds. 2000. Ecological Integrity: Integrating Environment, Conservation, and Health. Island Press.

Pojman LP, Pojman P, eds. 2012. Environmental Ethics: Readings in Theory and Application, 6th ed. Wadsworth.

Taylor PE. 1998. From environmental to ecological human rights: A new dynamic in international law. Georgetown International Environmental Law Review 10: 309.

Westra L. 2006. Environmental Justice and the Rights of Unborn and Future Generations: Law, Environmental Harm and the Right to Health. Earthscan.

LAURA WESTRA LauraWestra (lwestra@interlog.com) is a professor emerita of philosophy at the University of Windsor, in Ontario, Canada, and a sessional instructor with the Faculty of Law at the University of Milan, in Italy. 